Podsumowania trzydniowych obrad dokonała dr Dorota Sidorowicz-Mulak, kierownik Oddziału Starych Druków Biblioteki Ossolineum.

W programie konferencji znalazło się miejsce na uroczystą kolację oraz prezentację cymeliów ze zbiorów Oddziału Starych Druków. Dodatkową atrakcję stanowiła możliwość obejrzenia jubileuszowej wystawy „Nie Na marne. Sienkiewicz w kolekcji Ossolineum" oraz zwiedzanie Muzeum Pana Tadeusza.

Należy podkreślić zainteresowanie i aktywny udział słuchaczy w ciągu wszystkich dni konferencji. Każdej sesji towarzyszyła bowiem dyskusja, nawiązująca do wysłuchanych referatów. Mimo mnogości wystąpień, sala była zapełniona. Uczestnicy konferencji — głównie zagraniczni — na bieżąco relacjonowali jej przebieg w mediach społecznościowych.

Konferencja we Wrocławiu była pierwszym tego typu wydarzeniem i o tak szerokim zasięgu międzynarodowym. Pokazała także wysoki stopień zaawansowania badań proweniencyjnych w Polsce, co podkreślali badacze zagraniczni.

Materiały pokonferencyjne w całości ukażą się w formie książkowej. Z fragmentem możemy się już zapoznać. Część uczestników konferencji przedstawiła wyniki swoich, często wieloletnich, badań w formie referatów, część natomiast skorzystała z formy prezentacji w programie PowerPoint. Wszystkie przygotowane na konferencję prezentacje są już udostępnione na stronie Biblioteki ZNiO: https://ossolineum.pl/index.php/proweniencyjna-grupa-robocza/program-konferencji/

Jako postscriptum do sprawozdania z konferencji należałoby dodać jeszcze jedną informację. Jak się okazało, ożywiony panel dyskusyjny na temat stworzenia polskiej bazy proweniencyjnej przyniósł wymierne korzyści. Dyskusja w środowisku starodruczników jest kontynuowana. Powstał realny pomysł utworzenia w Polsce Narodowej Bazy Proweniencji. Być może wykorzystana zostanie w tym celu udostępniona bezpłatnie przez Uniwersytet w Oksfordzie struktura ich bazy MEI, będącej ogólnoeuropejską bazą proweniencji inkunabułów. Koordynacji zadań podjęło się Ossolineum. Już zaczęła działać Proweniencyjna Grupa Robocza, a efekty działalności będzie można śledzić na stronie internetowej, umieszczonej na serwerach ZNiO (https://ossolineum.pl/index.php/proweniencyjna-grupa-robocza/).

Weronika Karlak

\title{
„COLLECTIONS AND BOOKS [A]CROSS BORDERS” — SESJA ŚWIATOWEGO KONGRESU INTERNATIONAL FEDERATION OF LIBRARY ASSOCIATIONS AND INSTITUTIONS (IFLA), 21 SIERPNIA 2017
}

DOI: $10.19195 / 0080-3626.61 .26$

W dniach 19-25 sierpnia 2017 roku we Wrocławiu odbył się kongres International Federation of Library Associations and Institutions (Międzynarodowej Federacji Stowarzyszeń i Instytucji Bibliotekarskich, dalej: IFLA), w którym uczestniczyli bibliotekarze i bibliotekoznawcy z różnych stron świata. 
Powołana do życia w 1927 roku w Edynburgu IFLA zrzesza obecnie ponad 14 tysięcy bibliotek, stowarzyszeń i instytucji działających na rzecz bibliotek z ponad 140 państw1; w odbywających się raz do roku światowych kongresach uczestniczy średnio 3 tysiące osób $^{2}$. W Polsce tego typu wydarzenie miało miejsce po raz trzeci - w latach 1936 i 1959 kongresy zostały zorganizowane w Warszawie, w bieżącym roku — we Wrocławiu. Tegoroczne hasło przewodnie brzmiało „Libraries. Solidarity. Society” („Biblioteki. Solidarność. Społeczeństwo").

Większość sesji kongresu gościła Hala Stulecia, towarzyszyły im jednak spotkania poza tym centrum, czyli tzw. off-site sessions. Wśród nich znalazła się sesja pt. „Collections and Books [A]cross Borders” - w wolnym tłumaczeniu: „Zbiory i książki po drugiej stronie granic"3, zorganizowana 21 sierpnia w gmachu głównym Biblioteki Uniwersytetu Wrocławskiego przy ul. Fryderyka Joliot-Curie 12 przez dwie sekcje IFLA — Rare Books and Special Collections Section (Sekcję Książek Rzadkich i Zbiorów Specjalnych) oraz Indigenous Matters Section (Sekcję ds. Tubylczych).

O godzinie 9.00 rano zgromadzonych w sali konferencyjnej uczestników powitały Helen Vincent z National Library of Scotland (Szkockiej Biblioteki Narodowej) oraz Cellia Joe-Olsen reprezentująca Te Rōpū Whakahau - nowozelandzkie stowarzyszenie do spraw Maorysów, ich bibliotek oraz sposobu przekazywania informacji w środowisku tej ludności. Następnie głos zabrała dyrektor Biblioteki Uniwersytetu Wrocławskiego, st. kustosz dyplomowany Grażyna Piotrowicz, która po przywitaniu uczestników w progach kierowanej przez nią instytucji opowiedziała o jej rozwoju i zbiorach oraz ich digitalizacji. Uczestnicy mogli następnie wysłuchać przygotowanych na sesję wystąpień i referatów oscylujących tematycznie przede wszystkim wokół spraw bibliotek etnicznych oraz zbiorów, które w wyniku działań wojennych bądź przesunięcia granic przynależą obecnie do bibliotek obcych grup narodowych.

Pierwszy referat autorstwa Edgarda Civallera z Independent LIS Professional z Madrytu, zaprezentowany przez Marię Aurorę Díez Baños z Complutense University of Madrid, nosił tytuł Record my indigenous word; or, how special sound collections may break internal borders i dotyczył spraw ludności z argentyńskiej prowincji Chaco. Członkowie plemion Gran Chaco, znajdujący zatrudnienie głównie przy wyrębie lasu oraz produkcji bawełny, mają własną kulturę, języki i tradycje. Autor, który w latach 2001-2006 pracował w północno-wschodniej Argentynie, zdołał stworzyć znaczną liczbę niewielkich zbiorów nagrań legend i historii opowiadanych przez najstarszych przedstawicieli tej ludności. W ten sposób powstały swoiste biblioteki przechowujące bogatą spuściznę kulturową oraz języki plemion Gran Chaco. Nagrania odtwarza się w szkołach, przełamując barierę

1 Więcej informacji na stronie internetowej IFLA: https://www.ifla.org/about [dostęp: 11.10.2017].

2 Stowarzyszenie Bibliotekarzy Polskich [serwis internetowy], http://www.sbp.pl/ifla2017 [dostęp: 18.10.2017].

3 Across to 'po drugiej stronie', cross - 'przekraczać'; w angielskim tytule celowo wykorzystano grę słów, w referatach chodziło bowiem nie tylko o zbiory lub książki, które znalazły się poza granicami jakiegoś kraju, ale o możliwość ich udostępnienia lub zwrotu grupom narodowym czy etnicznym, które je stworzyły. 
pomiędzy najstarszym i najmłodszym pokoleniem i umożliwiając słuchaczom spisanie opowieści przodków. Tak stworzona literatura oraz nagrania stanowić będą wartość nie tylko dla przyszłych pokoleń ludności tubylczej, ale i antropologów oraz językoznawców badających wymierające języki.

Następny referat, [A]cross borders: U.S.-Mexico periodical project, przygotowały Lisa Cruces, Maira E. Álvarez i Sylvia Fernández Quintanilla z Uniwersytetu w Houston. Autorki rozpoczęły swoją prezentację od odtworzenia wypowiedzi Donalda Trumpa, obecnego prezydenta USA, który podczas kampanii wyborczej ogłosił, że zbuduje mur pomiędzy Meksykiem a Stanami Zjednoczonymi, aby chronić państwo przed niebezpiecznym elementem, jakim jest latynoska ludność z Meksyku. Autorki opowiedziały następnie o tym, jak zajmują się kulturowym pasem przygranicznym, tworząc zbiory i bazę latynoamerykańskich czasopism z okresów 1808-1846, 1847-1854 i 1855-1930. Do ich kategoryzacji wykorzystują standardy Biblioteki Kongresu. Dzięki projektowi, który realizują, są one szczególnie świadome bogatej i długiej historii kultury piśmiennej Latynosów zamieszkujących tereny Meksyku i stąd za dodatkowy cel swoich działań przyjęły odwrócenie obecnych w dyskursie politycznym negatywnych opinii na temat tej ludności.

Kolejną prelegentką była Eva Nilsson Nylander z Lund University Library w Szwecji z referatem Return to Kashgar: the Jarring Collection of Uyghur manuscripts. Rejon Kaszgaru, miasta położonego w zachodnich Chinach na skrzyżowaniu głównych dróg handlowych euroazjatyckiego jedwabnego szlaku, zamieszkiwała ludność bardzo zróżnicowana etnicznie, m.in. turecka, perska, arabska i chińska. Biblioteka w Lund przechowuje ok. 600 książek rękopiśmiennych z okresu od XVI do XX wieku pochodzących z Shache, Kaszgaru i Urumczi. Kolekcję tę, złożoną w sumie z ok. 1500 tytułów w różnych językach, zgromadził w latach 1929-1930 szwedzki filolog, późniejszy dyplomata, Gunnar Jarring (1907-2002), który zbierał w Kaszgarze materiały do swojej rozprawy doktorskiej na temat języków turkijskich. Pragnąc przywrócić ów niezwykły zbiór Kaszgarowi, szwedzka biblioteka podjęła się jego digitalizacji: książki w formacie cyfrowym, udostępniane bezpłatnie na stronie biblioteki w Lund, cieszą się zainteresowaniem głównie filologów.

Czwarty referat, Westward moving history of Hubei Provincial Library during the resistance against Japanese aggression and re-walking the history in the library's 111 years old, wygłosiła Xingyue Cao z Hubei Provincial Library w Chinach. Autorka opowiedziała o powstaniu reprezentowanej przez nią biblioteki w 1904 roku oraz o jej losach podczas agresji japońskiej w Chinach w latach 30. XX wieku. W lipcu 1938 roku, aby chronić dziedzictwo kulturowe, zbiory biblioteczne, złożone w owym czasie z ok. 98 tysięcy woluminów, w tym ponad 3 tysięcy książek rzadkich, przetransportowano korytem rzeki ze stolicy prowincji Hubei — Wuhan do górskiego miasta Enshi. Woluminy spakowano do drewnianych skrzyń, a pomiędzy karty włożono suszone liście tytoniu, aby zapobiec ich niszczeniu przez owady. Księgozbiór przechowano następnie w jaskiniach na górskich zboczach. W 1946 roku powrócił on do Wuhan w stanie prawie nienaruszonym (jedynie 944 książki zostały zniszczone lub zagubione), a bibliotekę wzbogacono o dodatkowe kilkanaście tysięcy woluminów pochodzących od darczyńców. Autorka podkreśliła, że transport i przechowanie niemal w całości zbiorów biblioteki podczas wojny jest czymś niespotykanym w historii bibliotek. 
Kolejny referat From China to Cambridge: modification of rare Chinese printed books within Cambridge college libraries przygotowała Françoise Richard. Opowiedziała ona o problemach z odnową i zabezpieczaniem cennych chińskich starodruków, które wymagają od fachowców specjalnego przygotowania. W przeszłości poddawano je zabiegom konserwatorskim, upodabniając np. ich oprawę do oprawy książek tworzonych w Europie. Dzisiaj w zbiorach bibliotek w Cambridge odnaleźć można m.in. chiński tekst, który, po dodaniu oprawy introligatorskiej, odwrócony jest do góry nogami. Poznanie odpowiednich sposobów konserwacji tego typu materiałów jest kluczowe dla ich właściwego przechowywania i udostępniania.

Referat Françoise Richard był ostatnim wygłoszonym w porannej części sesji; po południu zaprezentowano jeszcze cztery odczyty.

Ma Ascensión Hernández Vázquez i Rosa Díaz Burillo z UNED (Universidad Nacional de Educación a Distancia) w Madrycie przygotowały Latin classic incunabula printed in Spain: their transmission cross the borders — referat o inkunabułach z lat 1470-1500 pochodzących z różnych drukarni na terenie Hiszpanii. Stanowią one dzisiaj niezwykle cenne zabytki dotyczące hiszpańskiego renesansu i humanizmu, jednak większość z nich znajduje się poza terenem kraju, w bibliotekach amerykańskich lub innych państw europejskich. Prowadzone są badania nad ich rozproszeniem i lokalizacją.

Autorzy War booty at Uppsala University Library, Peter Sjökvist i Krister Östlund z Biblioteki Uniwersyteckiej w Uppsali, opowiedzieli o jej powstaniu i zwiększaniu jej zasobów. Założona w 1621 roku biblioteka w Uppsali wzbogaciła się znacznie za sprawą króla Gustawa II Adolfa, panującego w latach 1611-1632, który przekazał jej łupy przywiezione z wojny w Polsce. Kilkadziesiąt lat później w wyniku podobnych działań w zbiorach biblioteki znalazły się też książki pochodzące z Danii, Niemiec i Bohemii. Branie łupów wojennych jest dzisiaj zakazane, ale w owych czasach było legalne. Wspomniane książki z całą pewnością przekroczyły granice, stając się, zdaniem niektórych, rodzajem transferu kulturowego, co zakwestionowano w referacie.

Let our manuscripts talk about borders: a new look at the collection of the Bavarian State Library, referat Claudii Fabian z Bawarskiej Biblioteki Państwowej, dotyczył utraty przez Niemcy cennych książek związanych z historią kultury niemieckiej. Znajdują się one obecnie poza granicami Niemiec, w posiadaniu obcych grup narodowych, dla których nie stanowią tak istotnego elementu dziedzictwa kulturowego. Autorka zadała pytanie o możliwości ich odzyskania.

Ostatni referat, The ethical and legal framework for heritage acquisitions at the British Library, przygotowany przez Kristiana Jensena z British Library, miał charakter bardziej ogólny. Autor opowiedział o możliwościach legalnego zakupu pozycji do zbiorów bibliotecznych, co w Wielkiej Brytanii regulują adekwatne ustawy. Prawo ma przeciwdziałać kradzieży i wzbogacaniu zbiorów bibliotek i muzeów w pochodzące z niej elementy, a zarazem umożliwiać i ułatwiać odzyskiwanie zrabowanych przedmiotów przez jej prawowitych właścicieli. Niekiedy jednak dopiero zakupienie na aukcji całego zbioru, którego część stanowi element pochodzący z kradzieży, umożliwia w dalszej kolejności jego zwrot prawowitemu właścicielowi. Dlatego też, podejmując decyzję, za każdym razem należy kierować się przede wszystkim względami etycznymi. 
Sesję „Collections and Books [A]cross Borders” zakończyły obrady okrągłego stołu, w których udział wzięli: Claudia Fabian i Dorothea Sommer z Bawarskiej Biblioteki Państwowej, David Farneth z Getty Research Institute w USA, Kristian Jensen z British Library, Cellia Joe-Olsen ze stowarzyszenia Te Rōpū Whakahau i Helen Vincent ze Szkockiej Biblioteki Narodowej. W dyskusji podkreślano wartość nowych możliwości udostępniania zbiorów. Wielkie biblioteki, które radzą sobie z przechowywaniem dużych zbiorów, często borykają się z problemem ich udostępniania. Częściowym rozwiązaniem staje się digitalizacja zbiorów, choć jej proces bywa bardzo długi. Rozmawiano o tym, że transport niektórych zbiorów do krajów, z których oryginalnie pochodzą, jest czasem niemożliwy lub trudny do zorganizowania. Również w takich przypadkach najlepszym rozwiązaniem może okazać się digitalizacja. Podsumowując sesję, warto zauważyć, że referatów było zaledwie dziewięć, dzięki czemu znalazł się czas na wprowadzenia, opinie i résumé moderatorów, pytania i dyskusje po odczytach, uaktualnienie spraw ochrony dziedzictwa kulturowego, w którą IFLA angażuje się we współpracy z UNESCO, a także na rozmowy podczas przerw kawowych w kuluarach, pamiątkowe zdjęcie i lunch.

Anna Cisło

„EKSLIBRIS: ZNAK WŁASNOŚCIOWY — DZIEŁO SZTUKI. TRADYCJA, WSPÓŁCZESNOŚĆ, PERSPEKTYWY”. MIĘDZYNARODOWA KONFERENCJA NAUKOWA, KRAKÓW, UNIWERSYTET PEDAGOGICZNY IM. KOMISJI EDUKACJI NARODOWEJ, 15 LISTOPADA 2017

DOI: $10.19195 / 0080-3626.61 .27$

Dnia 15 listopada 2017 roku w Krakowie odbyła się międzynarodowa konferencja naukowa „Ekslibris: znak własnościowy — dzieło sztuki. Tradycja, współczesność, perspektywy". Organizatorem wydarzenia był Instytut Nauk o Informacji oraz Biblioteka Główna Uniwersytetu Pedagogicznego im. Komisji Edukacji Narodowej w Krakowie. Wydarzenie to znakomicie wpisało się w przypadający na 2017 rok jubileusz 500-lecia ekslibrisu polskiego. Zamiarem organizatorów było bowiem, by ta „rocznica stała się punktem wyjścia do podsumowania historii, omówienia współczesności i wskazania perspektyw funkcjonowania znaku własnościowego, który, przechodząc przez liczne ewolucje (m.in. technik, stylów), zatracił niemalże zupełnie swą pierwotną funkcję"".

Komitet naukowy tworzyli: dr hab. Krzysztof Marek Bąk (Uniwersytet Śląski w Katowicach), dr Łukasz Cywicki (Uniwersytet Rzeszowski), dr Marcin Cziomer (Krakowska Akademia im. Andrzeja Frycza Modrzewskiego), dr Agnieszka Fluda-Krokos (Uniwersytet Pedagogiczny im. Komisji Edukacji Narodowej w Krakowie), dr hab. Grzegorz Nieć

1 Zaproszenie. Ekslibris: znak własnościowy - dzieło sztuki. Tradycja, współczesność, perspektywy, Uniwersytet Pedagogiczny im. Komisji Edukacji Narodowej w Krakowie, Instytut Nauk o Informacji [serwis internetowy], http://exlibris.up.krakow.pl/index.php/zaproszenie/ [dostęp: 22.11.2017]. 